\title{
Discussion: Modelling the hydraulics of the Carlisle 2005 flood event
}

Matt S. Horritt PhD, CEng, MCIWEM

Specialist modeller, Halcrow Group Ltd, Burderop Park, Swindon, Wilts, UK

Paul D. Bates PhD

School of Geographical Sciences, University of Bristol, UK

Tim J. Fewtrell PhD

School of Geographical Sciences, University of Bristol, UK
David C. Mason PhD

Environmental Systems Science Centre, University of Reading, UK Matt D. Wilson PhD

University of the West Indies, St. Augustine, Trinidad and Tobago

Peter Spencer MSC, CEng, MICE, MCIWEM

Technical Specialist, Environment Agency, NW region, UK

\section{Contribution by P. Spencer}

1. Introduction

Following publication of the paper by Horritt et al. (2010), discussion between the authors and Peter Spencer of the Environment Agency (EA) North West Region raised a number of points that may be of interest to readers.

\section{Gauging station rating curves}

Rating curves of seven key flow gauging stations in the Eden catchment were reviewed after the 2005 floods, using 1D and hybrid 1D/2D models (Spencer et al., 2006). The 1D ISIS model of the Sheepmount gauging station gave very similar results to Figure 4 in the paper by Horritt et al. (2010), including the slight upward bend at the very highest flows, but the rating was not adjusted because the differences were small compared with the modelling uncertainties. The results from the simple finite volume (SFV) model for the Sheepmount and Cummersdale gauges can be viewed as consistent with other modelling approaches.

\section{Representation of roughness}

The EA's 1D ISIS models of this reach have variable in-channel Manning's $n$ roughness values, which are derived from standard tables of roughness and subsequent model calibration. The values are similar or a little higher than those quoted in the paper for the SFV model. This would be expected because the 1D values attempt to allow for all sources of roughness (including sinuosity, irregularity, etc.), which are partially accounted for in the 2D model. The contribution to Manning's $n$ from these effects is expected to be approximately 0.01-0.02 (from Cowan's method (Cowan, 1956), for example), and this is consistent with the differences seen between the 1D ISIS models and the SFV model.

The paper reports on the results of changing Manning's $n$ on the floodplain with values between 0.03 and 0.12 - a range that is larger than might be commonly met in $1 \mathrm{D}$ models. In view of the sometimes uncertain provenance of floodplain roughness in 1D models, the finding that water levels were insensitive to the floodplain Manning's $n$ is reassuring.

\section{Details of the January 2005 event}

It is worth clarifying a few statements in the paper about the January 2005 event (which do not significantly affect the modelling results), based on local knowledge of EA staff.

(a) The return period of the event is stated as 150 years in Section 1 of the paper; strictly, estimates have tended to be 'at least 150 years'.

(b) At the upstream boundary of the model, there was also flow in January 2005 through the flood relief culverts underneath the M6, whereas in the SFV model this was represented as only channel flow. This is expected to make little difference to the results, as the boundary is a significant distance upstream of the area of interest.

(c) In Section 4 of the original paper, the water levels at some bridges were described as being 'well below the soffit'. The peak level at the railway bridge downstream of the Sheepmount gauging station was around $0.4 \mathrm{~m}$ below the soffit; at Eden Bridge, the water level was around $1 \mathrm{~m}$ below.

(d) The gauging station at Cummersdale, described in Section 2.1 of the paper as a flat- $\mathrm{V}$ weir, does not conform to ISO flat- $\mathrm{V}$ weir dimensions and is better described as a nonstandard shallow-V weir (HiFlows-UK, 2010).

\section{REFERENCES}

Cowan WL (1956) Estimating hydraulic roughness. Agruicultural Engineering 37(7): 474-475.

HiFlows-UK (2010) See http://www.environment-agency.gov.uk/ hiflows/91727.aspx (accessed 18/10/2010).

Horritt MS, Bates PD, Fewtrell TJ, Mason DC and Wilson MD (2010) Modelling the hydraulics of the Carlisle 2005 flood event. Proceedings of the Institution of Civil Engineers, Water Management 163(6): 273-281.

Spencer P, Boswell D, Davison I and Lukey B (2006) Flood forecasting using real time hydraulic and other models: lessons from the Carlisle flood in January 2005. Proceedings of the 41st Defra Flood \& Coastal Management Conference, York. Defra, London. 